\title{
Nitrification and Nitrifying Bacteria in a Coastal Microbial Mat
}

\author{
Haoxin Fan ${ }^{1}$, Henk Bolhuis ${ }^{1}$ and Lucas J. Stal ${ }^{1,2 *}$ \\ 'Department of Marine Microbiology, Royal Netherlands Institute for Sea Research, Yerseke, Netherlands, ${ }^{2}$ Department of \\ Aquatic Microbiology, Institute of Biodiversity and Ecosystem Dynamics, University of Amsterdam, Amsterdam, Netherlands
}

\section{OPEN ACCESS}

Edited by:

Hongyue Dang,

Xiamen University, China

Reviewed by:

James T. Hollibaugh,

University of Georgia, USA

Anne Bernhard,

Connecticut College, USA

${ }^{*}$ Correspondence:

Lucas J. Stal

lucas.sta/@nioz.nl

Specialty section: This article was submitted to

Aquatic Microbiology,

a section of the journal

Frontiers in Microbiology

Received: 10 September 2015 Accepted: 17 November 2015

Published: 01 December 2015

Citation:

Fan H, Bolhuis H and Stal LJ (2015) Nitrification and Nitrifying Bacteria in a

Coastal Microbial Mat.

Front. Microbiol. 6:1367.

doi: 10.3389/fmicb.2015.01367
The first step of nitrification, the oxidation of ammonia to nitrite, can be performed by ammonia-oxidizing archaea (AOA) or ammonium-oxidizing bacteria (AOB). We investigated the presence of these two groups in three structurally different types of coastal microbial mats that develop along the tidal gradient on the North Sea beach of the Dutch barrier island Schiermonnikoog. The abundance and transcription of amoA, a gene encoding for the alpha subunit of ammonia monooxygenase that is present in both $A O A$ and $A O B$, were assessed and the potential nitrification rates in these mats were measured. The potential nitrification rates in the three mat types were highest in autumn and lowest in summer. $\mathrm{AOB}$ and $\mathrm{AOA}$ amoA genes were present in all three mat types. The composition of the $\mathrm{AOA}$ and $\mathrm{AOB}$ communities in the mats of the tidal and intertidal stations, based on the diversity of amoA, were similar and clustered separately from the supratidal microbial mat. In all three mats $A O B$ amoA genes were significantly more abundant than AOA amoA genes. The abundance of neither AOB nor AOA amoA genes correlated with the potential nitrification rates, but $A O B$ amoA transcripts were positively correlated with the potential nitrification rate. The composition and abundance of amoA genes seemed to be partly driven by salinity, ammonium, temperature, and the nitrate/nitrite concentration. We conclude that $\mathrm{AOB}$ are responsible for the bulk of the ammonium oxidation in these coastal microbial mats.

Keywords: ammonia-oxidation, amoA, microbial mat, nitrification, salinity

\section{INTRODUCTION}

Coastal microbial mats are compact, highly structured, small-scale ecosystems (Stal et al., 1985). These mats are built by cyanobacteria, oxygenic phototrophic bacteria, which through primary production enrich the sediment with organic matter. This organic matter forms the basis of a complex, multi-layered microbial ecosystem. An important process in these microbial mats is the fixation of dinitrogen $\left(\mathrm{N}_{2}\right)$ (Severin and Stal, 2010). $\mathrm{N}_{2}$ fixation has been intensively studied in microbial mats, but very little is known about the fate of the fixed nitrogen and about the functioning of the nitrogen cycle in microbial mats. In this study we investigated the oxidation of ammonium and assessed the seasonal variations in microbial mats located along a tidal salinity gradient.

Nitrification is the oxidation of ammonium to nitrate, which occurs in two steps, each carried out by specialist aerobic bacteria (Kowalchuk and Stephen, 2001). The first step, the oxidation of ammonia to nitrite (nitritification), is carried out by two distinct groups of microorganisms: ammonia-oxidizing bacteria (AOB) (two specific groups in beta- and gammaproteobacteria) and ammonia-oxidizing archaea $(\mathrm{AOA})$. The second step is the oxidation of nitrite to nitrate 
(nitratification) and is carried out by a specialist group of bacteria. No archaea are known to carry out this second reaction. The oxidation of ammonia to nitrite is the rate-limiting step in nitrification. Nitritification is also important because it provides the oxidant for anaerobic ammonium oxidation (anammox) (Jetten et al., 1998). Moreover, nitrite can also be reduced by denitrification (Davidson and Seitzinger, 2006). Both processes eventually lead to the formation of dinitrogen and thus represent a loss of bound nitrogen from the microbial mat ecosystem.

Metagenomic studies (Venter et al., 2004) and the isolation and cultivation of Nitrosopumilus maritimus (Könneke et al., 2005), a marine AOA, [now placed within the Thaumarchaeota (Brochier-Armanet et al., 2008)] suggested an important role for this group of organisms in ammonia oxidation in the marine environment. This finding challenged the view that bacteria are the main players of microbial ammonia oxidation and has led to a large volume of research for the presence of $\mathrm{AOA}$ and $\mathrm{AOB}$ in a wide range of ecosystems. The presence of ammonia oxidizers is usually determined through the detection of $a m o A$, the gene encoding the alpha subunit of ammonia monooxygenase, an enzyme that performs the first step in ammonia oxidation in both AOA and AOB. The ecological importance of AOA and AOB in nitrification has been determined in several studies. On the one hand, some studies reported that the archaeal amo $A$ genes outnumbered those of bacteria by orders of magnitudes (as was the case for example in the North Atlantic Ocean and in the North Sea (Wuchter et al., 2006), in Monterey Bay and near Hawaii (Mincer et al., 2007), and in several estuaries (Caffrey et al., 2007). On the other hand, some studies reported that bacterial $a m o A$ genes were more abundant than the archaeal amoA (Mosier and Francis, 2008; Christman et al., 2011). Since also gene or cell abundance do not necessarily reflect activity, the relative contribution of $\mathrm{AOA}$ and $\mathrm{AOB}$ to ammonia oxidation in coastal sediments remains uncertain. There is however good evidence for different niches for AOA and AOB. The former possesses a high affinity $\left(\right.$ low $\left.K_{\mathrm{m}}\right)$ for ammonia and therefore seems to particularly dominate environments that are very low in it, while the latter seems to prefer environments with high ammonia concentrations (Martens-Habbena et al., 2009). Compared to many terrestrial and marine environments, the ecology of ammonia oxidizer communities and their role in nitrification in coastal microbial mats have been poorly studied. AOA and AOB may be subject to different selection pressures that result from biotic and abiotic conditions and the different physiology that characterizes these organisms. A suite of environmental parameters may control nitrification in coastal sediments. These include besides ammonia, oxygen- and sulfide concentrations, the rate of carbon metabolism, and the presence or absence of vegetation or macro-fauna (Herbert, 1999). Coastal microbial mats harbor a multitude of potential environmental niches as the result of the large daily fluctuations of the key geochemical parameters such as: oxygen, $\mathrm{pH}$, and sulfide (Revsbech et al., 1983).

The aims of this study were to identify the ammonia oxidizing communities in the three types of microbial mats and to elucidate the factors that determine the abundance and activity of ammonia oxidizers. Therefore, we measured the potential rate of nitrification and investigated the diversity and abundance of $a m o A$ for $\mathrm{AOB}$ and $\mathrm{AOA}$ in three different mat types during four different seasons. We monitored the key environmental variables and linked them to changes in ammonia oxidizer communities and their activities (amoA gene transcripts).

\section{MATERIALS AND METHODS}

\section{Sampling}

The study site was located on the North Sea beach of the Dutch barrier island Schiermonnikoog. The geographical locations and descriptions of the three types of microbial mats (stations) that were sampled during this study as well as the vegetation and primary cyanobacterial species at these stations are presented in Table 1. The stations were located along a transect perpendicular to the beach covering the tidal gradient. Sampling was done five times during 2010 and 2011 to cover the four seasons. Samples were taken from the top $25-30 \mathrm{~mm}$ of the mat using custom-made transparent Lexan cylinder corers of $50 \mathrm{~mm}$ inner diameter and $60 \mathrm{~mm}$ height. The cores were transported back to the laboratory within $4 \mathrm{~h}$ of sampling and subsequently kept at ambient temperature and light. Incubation experiments for measuring the potential nitrification rate started within $24 \mathrm{~h}$ after sampling. Additional samples were taken from the natural mats for nucleic acid extraction. These samples were taken from the top $10 \mathrm{~mm}$ of the mat by using as a corer a $10-\mathrm{ml}$ syringe from which the needle connector was removed. These mat samples were divided into four equal parts using a scalpel, put into cryo-vials, and immediately frozen in the field in liquid nitrogen.

\section{Chemical Analyses}

For nutrient analyses $5 \mathrm{~g}$ mat sample (top $10 \mathrm{~mm}$ ) was extracted with $40 \mathrm{ml} 2 \mathrm{M} \mathrm{KCl}$. The extracts were filtered through Whatman $\mathrm{GF} / \mathrm{F}$ filters and the filtrates were kept at $-20^{\circ} \mathrm{C}$ until analysis (within a month). Nutrient (DIN and phosphate) concentrations were measured by a standard colorimetric method using an automated Segmented Flow Analyzer. Other mat samples were freeze-dried for the determination of total nitrogen (TN), total organic carbon (TOC) and C/N ratio by EA-IRMS (DELTA V Advantage; Thermo Fisher Scientific, Bremen, Germany).

\section{Potential Nitrification Rate}

The potential rate of nitrification was determined by using the ${ }^{15} \mathrm{~N}$ isotope dilution method by the addition of ${ }^{15} \mathrm{~N}$-labeled nitrate (Kirkham and Bartholomew, 1954). The measurements were performed in triplicate in the intact sediment cores. The ${ }^{15} \mathrm{~N}$ nitrate solution was injected into the sediment core. The needle was inserted fully into the sediment core and the syringe plunger was depressed while the needle was withdrawn out of the sediment as to distribute the label equally in the sediment. Four injections were made in each sediment core. Three cores from each station were frozen $\left(-20^{\circ} \mathrm{C}\right)$ immediately after the injection. The other cores were incubated at in situ temperature (Table 2) under a 12-12 h light-dark cycle for $24 \mathrm{~h}$. Subsequently, the inorganic nitrogen was extracted from the cores by $2 \mathrm{M} \mathrm{KCl}$. The nitrogen isotopic composition of $\mathrm{NO}_{\mathrm{x}}^{-}$was determined using 
TABLE 1 | The geographical coordinates and description of the mats investigated in this study.

\begin{tabular}{|c|c|c|c|c|}
\hline Station & Geographical coordinates & Description & Vegetation & $\begin{array}{l}\text { Dominant } \\
\text { cyanobacterial species }\end{array}$ \\
\hline \multirow[t]{8}{*}{ Station I } & \multirow[t]{8}{*}{$53^{\circ} 29.445^{\prime} \mathrm{N}, 6^{\circ} 8.718^{\prime} \mathrm{E}$} & \multirow{8}{*}{$\begin{array}{l}\text { Mainly freshwater influenced } \\
\text { site, close to the dunes. } \\
\text { Irregularly inundated }\end{array}$} & Elymus arctus & Nostoc \\
\hline & & & Juncus gerardi & Calothrix \\
\hline & & & Glaux maritima & Anabaena \\
\hline & & & Ammophila arenaria & Spirulina \\
\hline & & & Scirpus maritimus & Nodularia \\
\hline & & & & Synechocystis \\
\hline & & & & Merismopedia \\
\hline & & & & Gloeocapsa \\
\hline Station II & $53^{\circ} 29.460^{\prime} \mathrm{N}, 6^{\circ} 8.309^{\prime} \mathrm{E}$ & $\begin{array}{l}\text { Seawater influenced site, } \\
\text { developing microbial mat. At } \\
\text { the low water mark }\end{array}$ & No vegetation & $\begin{array}{l}\text { Lyngbya } \\
\text { Leptolyngbya }\end{array}$ \\
\hline Station III & $53^{\circ} 29.445^{\prime} \mathrm{N}, 6^{\circ} 8.342^{\prime} \mathrm{E}$ & $\begin{array}{l}\text { Seawater and freshwater } \\
\text { influenced site, located } \\
\text { between St1 and St2, at the } \\
\text { edge of the salt marsh }\end{array}$ & Salicornia sp. Puccinellia distans & $\begin{array}{l}\text { Microcoleus } \\
\text { Lyngbya }\end{array}$ \\
\hline
\end{tabular}

The cyanobacteria were identified by light microscopy based on their typical morphological characteristics.

the ammonia diffusion procedure according to Gribsholt et al. (2005). Briefly, to $60 \mathrm{ml} \mathrm{GF/F} \mathrm{(Whatman)} \mathrm{filtered} \mathrm{extract} 0.1 \mathrm{~g}$ $\mathrm{NaCl}$ and $300 \mathrm{mg} \mathrm{MgO}$ was added to convert $\mathrm{NH}_{4}^{+}$to $\mathrm{NH}_{3}$. The $\mathrm{NH}_{3}$ was trapped on an acidified $\left(\mathrm{H}_{2} \mathrm{SO}_{4}\right) 10 \mathrm{~mm}$ GF/D filter packet floating on the surface. After 8 days shaking at room temperature, the filter was removed. Subsequently, Devarda's Alloy $\left(75 \mathrm{mg}\right.$ ) was added to convert $\mathrm{NO}_{2}^{-}+\mathrm{NO}_{3}^{-}$to $\mathrm{NH}_{3}$, which was collected on a new acidified filter. The filters were dried for 2 days in an exicator and analyzed using a Flash EA-1112 series elemental analyzer coupled in-line via a conflo II interface with a Delta $S$ isotope ratio mass spectrometer (EA-IRMS, Thermo Fisher Scientific, Bremen, Germany). The rate of nitrification was calculated according to the equation of Norton and Stark (2011).

\section{Nucleic Acid Extraction and Geochip Analysis}

DNA and RNA were extracted using the MoBio UltraCLEAN soil DNA kit and the RNA PowerSoil ${ }^{\circledR}$ Total Isolation Kit, respectively (MoBio Laboratories, Inc., Carlsbad, CA, USA) according to the manufacturer's instructions. The quantity and quality were determined and checked by Nanodrop (Nanodrop ND1000, Thermo Scientific, Wilmington, DE, USA) and agarose gel electrophoresis, respectively. The RNA extracts were immediately treated with RNase free DNase I (Deoxyribonuclease I, Amplification Grade, Invitrogen Corporation, Carlsbad, CA, USA). Remaining DNA contamination of the RNA extracts was checked by PCR using the RNA extract as a template. RNA concentration and quality were checked again as described above. The DNA-free RNA was reverse transcribed to copy DNA using Superscript II Reverse Transcriptase and random primers (Invitrogen Corporation, Carlsbad, CA, USA) following the manufacturer's manual. Two controls were performed that either lacked reverse transcriptase or RNA. PCR reactions were performed to check the transcription to cDNA and controls were included as described above. The synthesized cDNA was kept at $-20^{\circ} \mathrm{C}$ until further use.

In addition, we used a functional gene microarray system, the GeoChip ( $\mathrm{Tu}$ et al., 2014), containing probes for genes involved in the majority of important biogeochemical nutrient cycles. For this study, we extracted data from the GeoChip for amoA genes ( $\sim 1340$ probes). We analyzed DNA samples from July 2010 and January 2011 by the GeoChip 4.2. DNA was extracted from triplicate samples from each of the three types of microbial mats. The DNA was purified using UltraClean 15 DNA purification Kit (MoBio Laboratories, Inc., Carlsbad, CA, USA) in order to achieve the quality necessary for hybridization on the chip. The DNA quantity was measured using the Nanodrop ND-1000 system. The procedures for DNA labeling and microarray hybridization followed previously established protocols (Wu et al., 2006). Briefly, $800 \mathrm{ng}$ DNA was labeled with fluorescent $\mathrm{Cy}-5$ dye by random priming and re-suspended in $50 \mu \mathrm{l}$ hybridization solution ( $40 \%$ formamide, $5 \times$ SSC, $5 \mu \mathrm{g}$ of unlabeled herring sperm DNA (Promega, Madison, WI), and $0.1 \%$ SDS $)$ and $2 \mu \mathrm{l}$ universal standard DNA (0.2 pmol $\mu 1^{-1}$ ) labeled with the fluorescent Cy-3 dye (Liang et al., 2010), denatured for $5 \mathrm{~min}$ at $95^{\circ} \mathrm{C}$ and maintained at $50^{\circ} \mathrm{C}$ until loaded onto the microarray slides. Arrays were hybridized on a MAUI Hybridization Station (Roche, South San Francisco, CA) for $12 \mathrm{~h}$ at $42^{\circ} \mathrm{C}$. The hybridized microarrays were scanned by a ScanArray Express (Perkin- Elmer, Wellesley, MA) at 95\% laser power and $85 \%$ photomultiplier tube gain. The resulting images were analyzed by ImaGene with signals processed as $\mathrm{SN}>2.0$ (signal to noise ratio).

\section{Quantitative PCR (qPCR) Analysis}

qPCR analyses were run on a Corbett Rotor-Gene 6000 TM (Corbett Life Science, Sydney, Australia). The copy numbers 
TABLE 2 | Physicochemical parameters in the microbial mats during the 2010-2011 sampling period.

\begin{tabular}{|c|c|c|c|c|c|}
\hline \multirow[t]{2}{*}{ Temperature $\left({ }^{\circ} \mathrm{C}\right.$, sediment) } & July (2010) & September (2010) & November (2010) & January (2011) & April (2011) \\
\hline & 17 & 10 & 9 & 0 & 8 \\
\hline \multicolumn{6}{|l|}{ ST1 } \\
\hline $\mathrm{NH}_{4}^{+}(\mu \mathrm{mol} / \mathrm{l})$ & $128.9 \pm 3.0$ & $83.7 \pm 17.3$ & $252.4 \pm 25.6$ & $191.3 .5 \pm 23.4$ & $233.1 \pm 23.7$ \\
\hline $\mathrm{NO}_{\bar{X}}^{-}(\mu \mathrm{mol} / \mathrm{l})$ & $23.3 \pm 4.6$ & $8.4 \pm 1.1$ & $11.4 \pm 2.1$ & $9.6 \pm 4.6$ & $25.9 \pm 3.4$ \\
\hline $\mathrm{TOC}(\%)$ & 0.04 & 0.06 & 0.04 & 0.04 & 0.04 \\
\hline $\mathrm{TN}(\%)$ & 0.006 & 0.01 & 0.006 & 0.007 & 0.007 \\
\hline $\mathrm{C} / \mathrm{N}$ & 6.7 & 6.0 & 6.7 & 5.7 & 5.7 \\
\hline Salinity(psu) & 18 & 19 & 15 & 15 & 17 \\
\hline \multicolumn{6}{|l|}{ ST2 } \\
\hline $\mathrm{NH}_{4}{ }^{+}(\mu \mathrm{mol} / \mathrm{l})$ & $587.9 \pm 41.2$ & $216.2 \pm 69.8$ & $1094 \pm 91.3$ & $736.8 \pm 199.6$ & $486.1 \pm 61.3$ \\
\hline $\mathrm{NO} x-(\mu \mathrm{mol} / \mathrm{l})$ & $22.4 \pm 14.7$ & $8.7 \pm 1.4$ & $9.8 \pm 3.2$ & $6.2 \pm 1.1$ & $20.6 \pm 4.5$ \\
\hline TOC(\%) & $0.19 \pm 0.01$ & $0.20 \pm 0.03$ & $0.13 \pm 0.02$ & $0.20 \pm 0.03$ & $0.17 \pm 0.02$ \\
\hline $\mathrm{TN}(\%)$ & 0.03 & 0.04 & 0.02 & 0.03 & 0.03 \\
\hline $\mathrm{C} / \mathrm{N}$ & 6.3 & 5.0 & 6.5 & 6.7 & 5.7 \\
\hline Salinity(psu) & 28 & 28 & 29 & 30 & 28 \\
\hline \multicolumn{6}{|l|}{ ST3 } \\
\hline $\mathrm{NH}_{4}+(\mu \mathrm{mol} / \mathrm{l})$ & $217.3 \pm 102.3$ & $255.9 \pm 68.4$ & $782.6 \pm 158.5$ & $510.2 \pm 62.2$ & $475.8 \pm 3.5$ \\
\hline $\mathrm{NO}_{X}-(\mu \mathrm{mol} / \mathrm{l})$ & $16.0 \pm 3.7$ & $7.6 \pm 1.9$ & $6.6 \pm 1.9$ & $2.8 \pm 0.6$ & $19.6 \pm 4.0$ \\
\hline TOC(\%) & $0.11 \pm 0.03$ & $0.15 \pm 0.02$ & $0.18 \pm 0.02$ & $0.15 \pm 0.02$ & $0.13 \pm 0.02$ \\
\hline TN(\%) & 0.02 & 0.03 & 0.03 & 0.03 & 0.02 \\
\hline $\mathrm{C} / \mathrm{N}$ & 5.5 & 5.0 & 6.0 & 5.0 & 6.5 \\
\hline Salinity(psu) & 25 & 25 & 23 & 22 & 23 \\
\hline
\end{tabular}

TOC, total organic carbon; TN, Total nitrogen.

of $\mathrm{AOB}$ and $\mathrm{AOA}$ were determined by primers amoA- $1 \mathrm{~F}$ and amoA-2R $\left(\mathrm{Tm}=53^{\circ} \mathrm{C}\right)$ (Rotthauwe et al., 1997) and by CrenAmoAQ-F (Mincer et al., 2007) and Arch-AmoA-R (Tm $=51^{\circ} \mathrm{C}$ ) (Francis et al., 2005), respectively. We determined the gene copy number in the mat samples in triplicate. Standard curves were made by dilution series of linearized plasmids (quantified by Nanodrop before using as standard for quantification) containing the target genes and were run in parallel with each analysis as well as with non-template controls. The reaction mixture $(15 \mu \mathrm{l})$ contained $7.5 \mu \mathrm{l}$ of Absolute $^{\mathrm{TM}}$ QPCR SYBR ${ }^{\circledR}$ Mix (Thermo Fisher Scientific, Rockford, IL, USA), $0.2 \mathrm{pmol} / \mu \mathrm{l}$ primers, $1 \mu \mathrm{l}$ template and sterilized MQ water. Cycling conditions were as follows: $95^{\circ} \mathrm{C} 15 \mathrm{~min}, 45$ cycles of $15 \mathrm{~s} 95^{\circ} \mathrm{C}, 20 \mathrm{~s} \mathrm{Tm}$, and $20 \mathrm{~s}$ at $72^{\circ} \mathrm{C}$, followed by melting curve analysis $\left(50-95^{\circ} \mathrm{C}\right)$. The standard curves spanned a range from 15 to $1.7 \times 10^{6}$ copies per $\mu l$ for the $\beta$ $\mathrm{AOB}$ and 2.2 to $1.2 \times 10^{6}$ copies per $\mu \mathrm{l}$ for the AOA. PCR efficiencies (E) and correlation coefficients for $\beta$-AOB were $78-88 \%$ and $R^{2}=0.99$ and for $\mathrm{AOA}$ were $85-98 \%$ and $R^{2}=0.99$.

\section{Sequences and Statistical Analysis}

Ammonia monooxygenase alpha subunit amino acid sequences obtained from GeoChip hybridization (50-mer oligonucleotide probes) and some reference sequences retrieved from GenBank were used to produce neighbor-joining trees and the reliability of the phylogenetic reconstructions was evaluated by bootstrapping (1000 replicates) using MEGA 6 (Molecular Evolutionary
Genetics Analysis, http://www.megasoftware.net) (Tamura et al., 2013).

In order to summarize the shared genes at station and season level, the genes detected in the three replicates of each station from July 2010 and January 2011 by the GeoChip were deployed as one pool (mean value from the three replicates). The determination of the shared genes, unique genes and diversity indices was done using an online pipeline (http://ieg.ou.edu/). The proportion of shared genes of two stations was calculated as the number of shared genes divided by the total number of genes detected in these stations. The proportion of unique genes at each station was calculated as the number of unique genes at each station divided by the total number of genes detected at that station.

Cluster analysis, multi-response permutation procedure (MRPP) and canonical correspondence analysis (CCA) (see below) were made based on the community data from the GeoChip. Cluster analysis of the community composition was done using PAST (http://folk.uio.no/ohammer/past/). MRPP (Bonferroni-corrected) using Bray-Curtis distance was used to test for significant differences in community composition. The MRPP was carried out in the open source software R (Team, 2011), using vegan package (Oksanen, 2011). The MRPP Astatistics describes the within and between group relatedness relative to what is expected by chance. A $p<0.05$ and an Astatistics $>0.1$ is considered to be a significant difference between groups (McCune et al., 2002). In order to test the relationship between the community composition and the environmental 
variables, CCA was carried out using Canoco 4.5 for Windows (ter Braak, 1989). The significance of the whole canonical model was tested by 999 permutations. One-way ANOVA, correlation test (Spearman and Pearson), and stepwise regression were carried out in SigmaPlot (Version12). Stepwise regression was carried out to test the influence of the environmental factors and abundance of amoA gene and transcript on potential nitrification rates.

\section{RESULTS}

\section{Phylogeny of amoA}

In all microbial mats, $\mathrm{AOB}$ amoA genes were detected belonging to Beta- and Gammaproteobacteria (Figure 1A). The majority (>98\% signal intensities) AOB amoA sequences retrieved from the GeoChip hybridizations belonged to Betaproteobacteria ( $\beta$ AOB). Among the Betaproteobacteria, the sequences clustered with Nitrosospira and Nitrosomonas. The sequences belonging to Nitrosospira can be subdivided into three major clusters (Table 3). Several cultivated species, such as Nitrosospira multiformis (AAC25057), Nitrosospira briensis and Nitrosospira sp. REGAU (AAV34189) were detected. 8.0\% of the sequences obtained from the GeoChip belong to Nitrosospira cluster C. Nitrosovibrio sp. FJ182 (ABB69924) and some uncultured clones were detected that grouped in cluster $\mathrm{C}$. The sequences belonging to Nitrosomonas can be sub-divided into four major clusters (Table 3). The nomenclature suggested by Purkhold et al. (2003) and Francis et al. (2003) was used. At all stations, the shifts between different groups were minor. Phylogenetic analysis revealed a broad distribution of archaeal amo $A$ genes (Figure 1B). The nomenclature suggested by Pester et al. (2012) was used. 41.1, 14.7, 37.9, and $6.3 \%$ of the total number of sequences obtained from the GeoChip fell into Nitrosopumilus, Nitrosotalea, Nitrososphaera, and others, respectively (Table 3). Based on the GeoChip signal intensities, Nitrosopumilus and Nitrososphaera were predominant and accounted for respectively $39.6-45.5 \%$ and $28.7-34.3 \%$ of total AOA amoA gene signal intensities. Nitrosotalea accounted for $16.5-20.3 \%$ of the total AOA amoA gene signal intensities. Other groups accounted for the remaining $6.9-9.3 \%$ of the total AOA amoA gene signal intensities. In none of the stations shifts between different groups were observed.

\section{$A O B$ and AOA Diversity and Community Composition}

The diversity of $\mathrm{AOA}$ and $\mathrm{AOB}$ amoA genes revealed by the GeoChip analysis is summarized in Table 4. The GeoChip detected a total of 112 AOB amoA sequences. The average number of AOB amoA sequences at Station 1 (July), Station 2 (July), Station 3 (July), Station 1 (January), Station 2 (January), and Station 3 (January) was 103, 94, 62, 85, 68, and 49, respectively (Table 4). Fourteen sequences were unique, meaning that they were detected only at one station and in one season. In July, Station 1 harbored 9 unique sequences, which was $8.7 \%$ $(9 / 103)$ of the total number detected. Station 2 and Station 3 harbored $3.2 \%(3 / 94)$ and $1.6 \%(1 / 62)$ unique sequences,

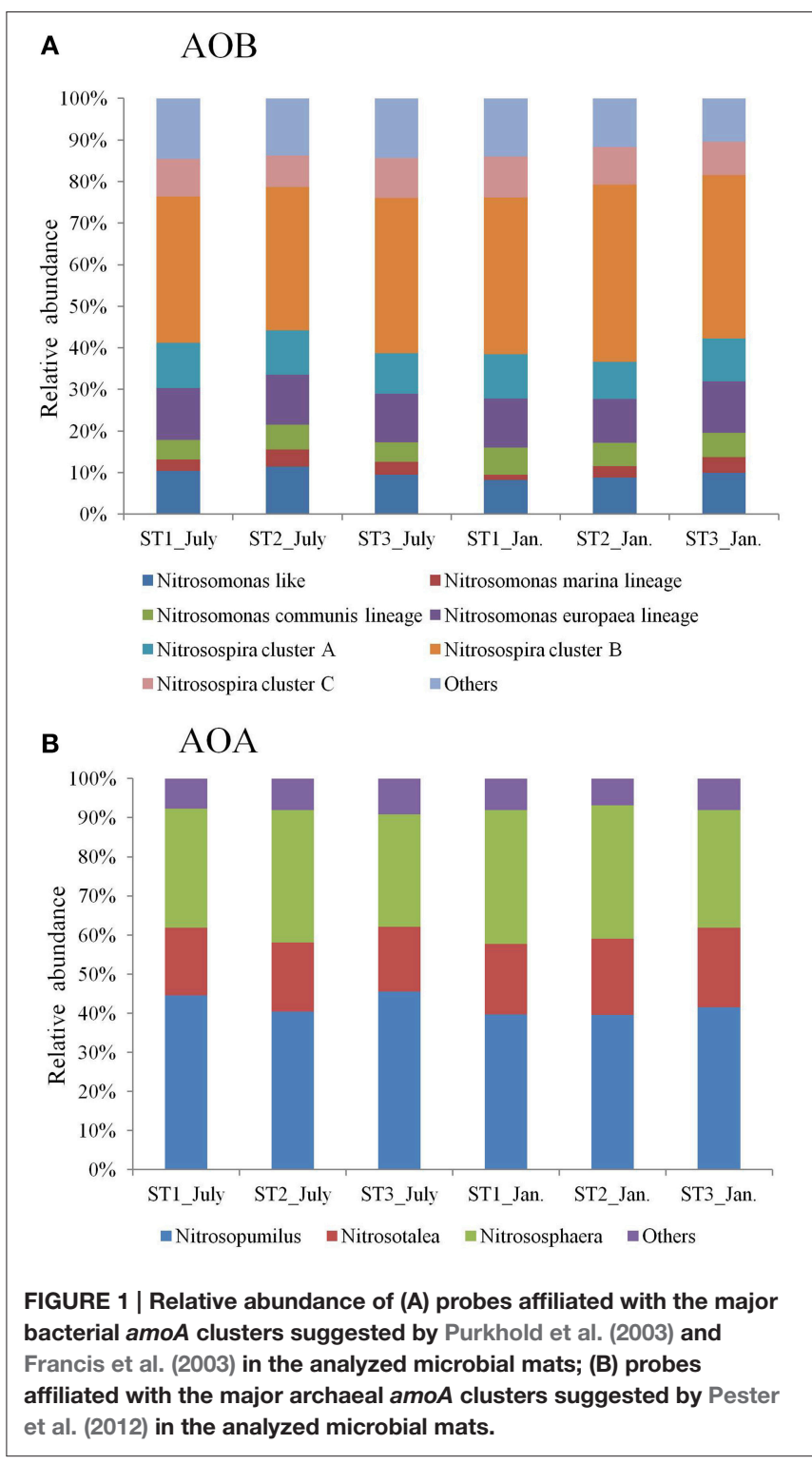

respectively. In January, the number of unique sequences in Station 1 dropped to 1 , which was only $1.2 \%(1 / 85)$ of the total number detected. No unique sequences were observed in January at Station 2 and Station 3. Pairwise comparison of AOB $a m o A$ sequences showed a high number of shared $\mathrm{AOB}$ amoA sequences between July and January as well as between the stations: $79.1 \%$ (Station 1 July and January), 68.8\% (Station 2 July and January), 70.8\% (Station 3 July and January), 61.3-83.0\% (Station 1 and Station 2), 44.8-57.5\% (Station 1 and Station 3), and $52.1-62.5 \%$ (Station 2 and Station 3).

We detected 95 AOA amoA sequences in the mats. The highest number of AOA $a m o A$ sequences was detected in July at Station 1 (80). We detected 77, 57, 76, 59, and 51 AOA amoA sequences at Station 2 (July), Station 3 (July), Station 1 (January), Station 2 (January), and Station 3 (January), respectively (Table 4). A considerable number of AOA amoA sequences were also shared between stations and seasons (Table 4). The highest 
TABLE 3 | Summary of the percentage of different types of amoA detected at each station.

\begin{tabular}{|c|c|c|c|c|c|c|}
\hline & ST1_July (\%) & ST2_July (\%) & ST3_July (\%) & ST1_Jan. (\%) & ST2_Jan. (\%) & ST3_Jan. (\%) \\
\hline \multicolumn{7}{|l|}{ AOB } \\
\hline Nitrosomonas like & 10.3 & 11.4 & 9.5 & 8.3 & 8.8 & 9.9 \\
\hline Nitrosomonas marina lineage & 2.8 & 4.1 & 3.1 & 1.2 & 2.8 & 3.8 \\
\hline Nitrosomonas communis lineage & 4.6 & 6.0 & 4.7 & 6.6 & 5.6 & 5.8 \\
\hline Nitrosomonas europaea lineage & 12.5 & 11.9 & 11.7 & 11.8 & 10.5 & 12.4 \\
\hline Nitrosopira cluster A & 10.9 & 10.7 & 9.7 & 10.7 & 9.0 & 10.3 \\
\hline Nitrosopira cluster B & 35.2 & 34.5 & 37.4 & 37.7 & 42.6 & 39.3 \\
\hline Nitrosopira cluster C & 9.1 & 7.5 & 9.6 & 9.8 & 9.0 & 8.0 \\
\hline Others & 14.6 & 13.8 & 14.4 & 14.0 & 11.7 & 10.5 \\
\hline \multicolumn{7}{|l|}{ AOA } \\
\hline Nitrosopuilus & 44.5 & 40.4 & 45.5 & 39.7 & 39.6 & 41.5 \\
\hline Nitrosotalea & 17.3 & 17.7 & 16.5 & 17.9 & 19.4 & 20.3 \\
\hline Nitrososphaera & 30.5 & 33.9 & 28.7 & 34.3 & 34.1 & 30.0 \\
\hline Others & 7.7 & 8.1 & 9.3 & 8.0 & 6.9 & 8.1 \\
\hline
\end{tabular}

The percentages were calculated by dividing the hybridization intensity of each gene type on the GeoChip by the total signal intensity of all $A O B$ or $A O A$ genes detected on the array.

TABLE 4 | Summary of $A O B$ and $A O A$ amoA detected by GeoChip, including the number and percentage of shared (italic) and unique (bold) sequences, and the diversity indices for each station.

\begin{tabular}{|c|c|c|c|c|c|c|}
\hline & ST1_July & ST2_July & ST3_July & ST1_Jan. & ST2_Jan. & ST3_Jan. \\
\hline \multicolumn{7}{|l|}{ АОВ } \\
\hline ST2_July & & $3(3.19 \%)$ & $60(62.50 \%)$ & $77(75.49 \%)$ & $66(68.75 \%)$ & $49(52.13 \%)$ \\
\hline ST3_July & & & $1(1.61 \%)$ & $54(58.06 \%)$ & $51(64.56 \%)$ & $46(70.77 \%)$ \\
\hline ST1_Jan. & & & & $1(1.18 \%)$ & 64(77.91\%) & $46(50.56 \%)$ \\
\hline Richness* & 103 & 94 & 62 & 85 & 68 & 49 \\
\hline Shannon-Weaver & 4.8 & 4.7 & 4.3 & 4.7 & 4.5 & 4.2 \\
\hline \multicolumn{7}{|l|}{ AOA } \\
\hline ST1_July & $5(6.3 \%)$ & 69(78.4\%) & $52(61.2 \%)$ & 68(77.3\%) & $53(61.6 \%)$ & $46(54.1 \%)$ \\
\hline ST2_July & & $3(3.9 \%)$ & $56(71.8 \%)$ & 65(73.9\%) & $57(72.2 \%)$ & $50(64.1 \%)$ \\
\hline ST3_Jan. & & & & & & $1(2.0 \%)$ \\
\hline Richness* & 80 & 77 & 57 & 76 & 59 & 51 \\
\hline Shannon-Weaver & 2.9 & 2.9 & 2.7 & 2.9 & 2.7 & 2.7 \\
\hline
\end{tabular}

${ }^{*}$ Richness is determined as probe numbers detected.

Shannon index was observed at Station 1 and the lowest was at Station 3, irrespective the time of sampling.

Cluster analysis revealed that the AOB community composition (based on the amoA gene diversity) was largely the same in summer and winter in each of the Stations 1 and 3. Station 2 and Station 3 clustered and were dissimilar from Station 1 (Figure 2A). A similar distribution was also found for the AOA community: Station 2 and Station 3 were more similar and separated from the community of Station 1 . In addition, the July AOA community composition was separated from that of January in the Stations 2 and 3 (Figure 2B).
MRPP statistics was carried out to test the differences of the $\mathrm{AOB}$ and $\mathrm{AOA}$ amoA composition between the stations and seasons (July and January) based on the GeoChip data. When the data from July or January were analyzed individually, no significant differences were observed between stations. When the data from the two seasons were combined, distinct communities of $\mathrm{AOB}$ and AOA were found in Station 1 when compared to stations $3(p<0.05)$ (Table 5). Stations 2 and 3 did not show significant different ammonia-oxidizer communities nor did station 1 differ from station $2(p>$ 0.05) (Table 5). There were no seasonal differences in the 
A

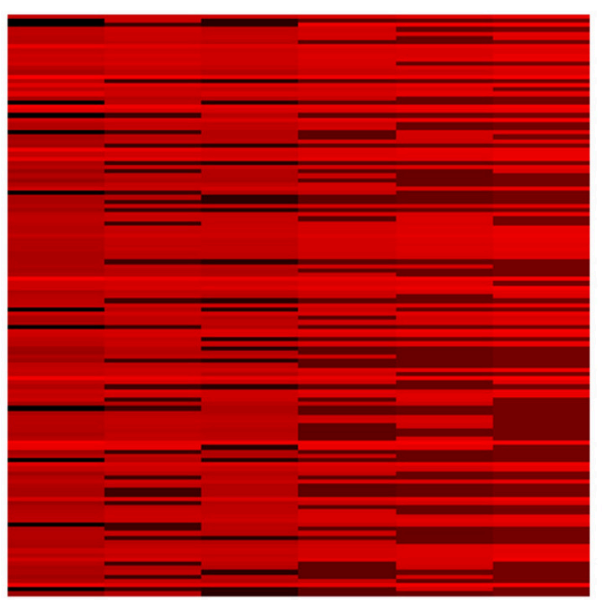

B AOA
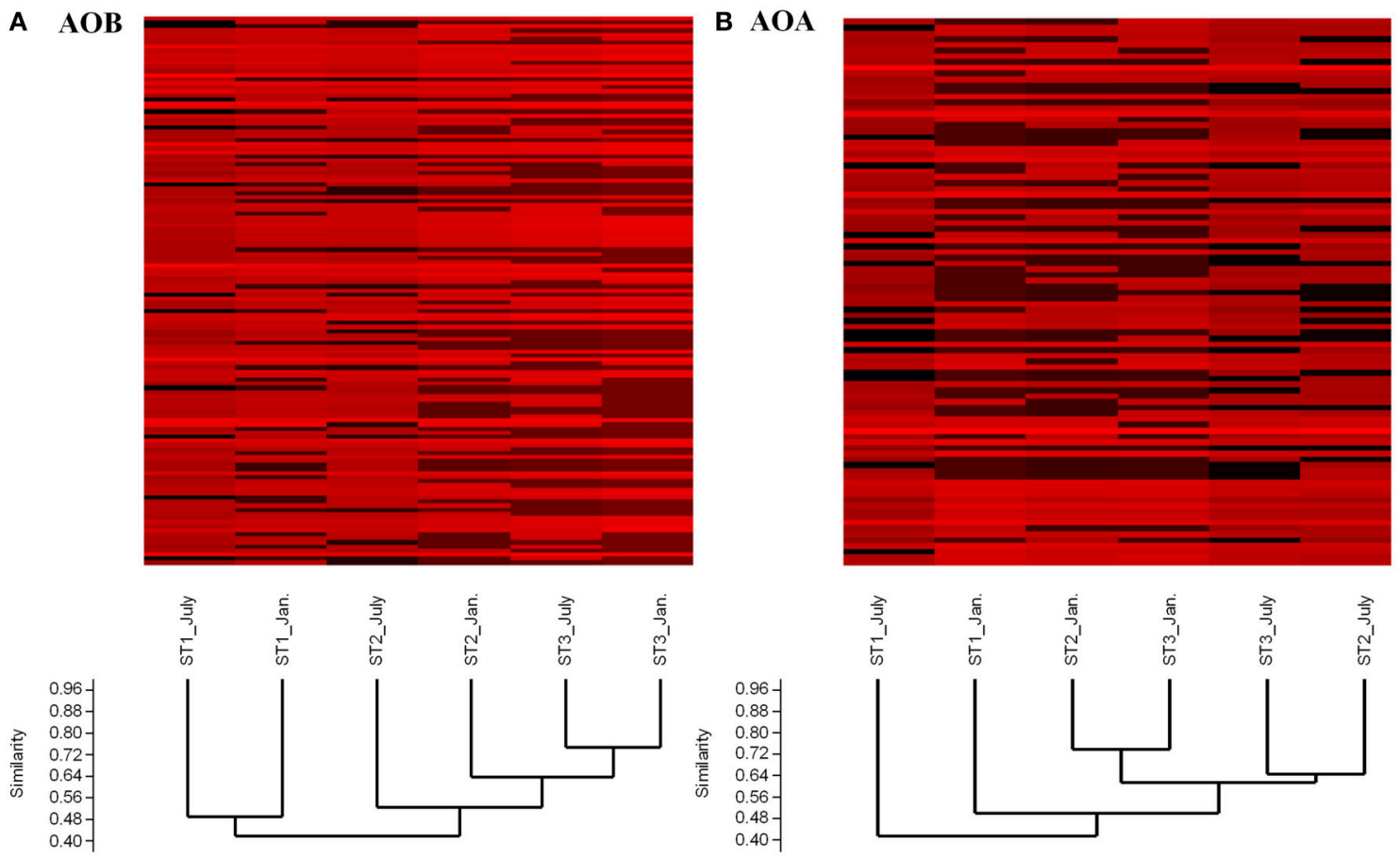

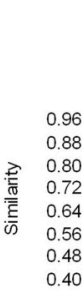

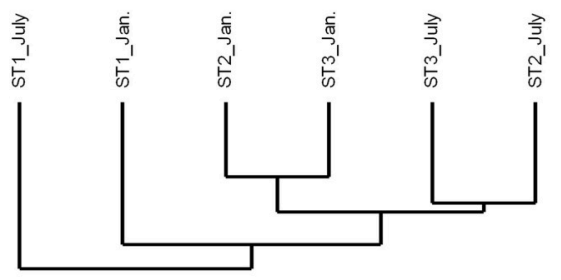

FIGURE 2 | Cluster analysis of amoA community composition at the different sampling stations. (A) Cluster analysis of betaproteobacterial amoA gene composition (B) Cluster analysis of archaeal amoA gene composition. Sample codes consist of the sampling station and the month of sampling.

TABLE 5 | Multi-response permutation procedure A-values of the ammonia oxidizing community composition.

\begin{tabular}{lc}
\hline \multicolumn{2}{c}{ Difference between group } \\
\hline Spatial differences & A-value \\
\hline AOA & \\
ST1 vs. ST2 & $0.135(p=0.096)$ \\
ST1 vs. ST3 & $0.3568(p=0.012)^{*}$ \\
ST2 vs. ST3 & $0.065(p=0.285)$ \\
AOB & \\
ST1 vs. ST2 & $0.135(p=0.09)$ \\
ST1 vs. ST3 & $0.3645(p=0.015)^{\star}$ \\
ST2 vs. ST3 & $0.04(p=0.495)$
\end{tabular}

*Means $p<0.05$ (statistical difference between $A O A$ and $\beta$-AOB amoA profiles assessed using multi-response permutation procedure).

ammonia-oxidizer communities in any of the stations (data not shown).

\section{$A O B$ and $A O A$ Abundance and Activity}

Abundance of archaeal and bacterial $a m o A$ genes was quantified in three stations from different seasons. Because of a negligible signal for nitrifiers belonging to the Gammaproteobacteria, we focus on $\beta$-AOB. $\beta$-AOB amo $A$ genes were detected in all three stations and in all seasons except at Station 1 in September. The numbers ranged from below detection level to $1.7 \times 10^{7}$ copies $\mathrm{g}^{-1}$ (sediment) (Table 6). The highest number of $\beta$-AOB amo $A$ genes was always observed in January at all stations. AOB amoA gene was undetectable in September and April at Station 1. The lowest $\beta$-AOB amo $A$ gene abundance at Stations 2 and 3 was observed in November and April, respectively. $\beta$-AOB amoA gene abundance increased from the station at the dunes to the low water mark in three of the four seasons tested, the exception was that in November the highest value was found in the intertidal Station 3. AOA amoA copies ranged from below detection level to $1.2 \times 10^{4}$ copies $g^{-1}$ sediment. AOA $a m o A$ was undetectable at Station 1, irrespective of the season, and in April at Station 3. The highest number of AOA amoA copies was detected in January at Station 2 . The $\beta$-AOB amoA copy number was significantly $(p<0.05)$ higher in all samples except in September at Station 1 when neither $\beta$-AOB nor AOA amoA genes were detected. $\beta$ AOB amoA abundance was significantly correlated (Spearman, $r=0.70, p<0.01)$ with AOA amoA abundance.

The expression of $\beta$-AOB amoA was detected in four of the 5 months at Station 1 (undetectable in November) and Station 3 (undetectable in July) with highest expression in April and November, respectively. At Station 2, the $\beta$-AOB amoA expression was only detected in September and November. Gene expression of AOA amoA was below the limit of detection in all samples.

\section{Relationship of Ammonia Oxidizer Community with Environmental Variables}

Canonical correspondence analysis showed that ammonia oxidizer (AOA and AOB) communities were significantly 


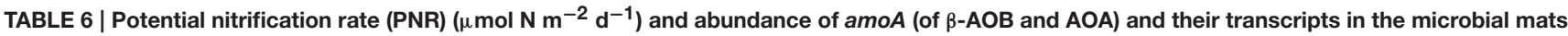
during the 2010-2011 sampling period (copies $\mathrm{g}^{-1}$ sediment).

\begin{tabular}{|c|c|c|c|c|c|c|c|c|c|c|}
\hline & \multicolumn{2}{|c|}{ July } & \multicolumn{2}{|c|}{ September } & \multicolumn{2}{|c|}{ November } & \multicolumn{2}{|c|}{ January } & \multicolumn{2}{|c|}{ April } \\
\hline & & SD & & SD & & SD & & SD & & SD \\
\hline \multicolumn{11}{|l|}{ STATION 1} \\
\hline PNR & n.d. & & 43.5 & 15.6 & 463.7 & 103.7 & 356.9 & 86.3 & 248.7 & 27.0 \\
\hline AOB DNA & 550 & 100 & n.d. & & 99 & & $3.4 \times 10^{5}$ & $5.9 \times 10^{4}$ & n.d. & \\
\hline AOB cDNA & 86 & 150 & $2.0 \times 10^{3}$ & $1.7 \times 10^{3}$ & n.d. & & 290 & 510 & 970 & 390 \\
\hline AOA DNA & n.d. & & n.d. & & n.d. & & n.d. & & n.d. & \\
\hline AOA cDNA & n.d. & & n.d. & & n.d. & & n.d. & & n.d. & \\
\hline \multicolumn{11}{|l|}{ STATION 2} \\
\hline PNR & 102.8 & 23.6 & 33.6 & 12.8 & 274.9 & 17.8 & 327.8 & 96.4 & 97.5 & 55.4 \\
\hline AOB DNA & $8.2 \times 10^{6}$ & $5.8 \times 10^{6}$ & $2.3 \times 10^{5}$ & $1.2 \times 10^{5}$ & $1.4 \times 10^{5}$ & $5.6 \times 10^{4}$ & $1.7 \times 10^{7}$ & $6.2 \times 10^{6}$ & $1.8 \times 10^{6}$ & $8.5 \times 10^{5}$ \\
\hline AOB cDNA & n.d. & & 360 & 250 & $3.9 \times 10^{3}$ & $2.2 \times 10^{3}$ & n.d. & & n.d. & \\
\hline AOA DNA & 460 & 390 & 210 & 66 & 150 & 340 & $1.0 \times 10^{4}$ & $4.6 \times 10^{3}$ & $5.9 \times 10^{3}$ & 55 \\
\hline AOA cDNA & n.d. & & n.d. & & n.d. & & n.d. & & n.d. & \\
\hline \multicolumn{11}{|l|}{ STATION 3} \\
\hline PNR & 177.4 & 15.2 & 57.5 & 31.7 & 300.3 & 56.8 & 537.0 & 99.2 & 237.7 & 86.4 \\
\hline AOB DNA & $1.1 \times 10^{5}$ & $2.6 \times 10^{4}$ & $5.4 \times 10^{5}$ & $3.3 \times 10^{5}$ & $3.8 \times 10^{6}$ & $1.2 \times 10^{6}$ & $4.9 \times 10^{6}$ & $1.9 \times 10^{6}$ & $8.9 \times 10^{3}$ & $2.5 \times 10^{3}$ \\
\hline AOB cDNA & n.d. & & 830 & 140 & $3.5 \times 10^{3}$ & $2.1 \times 10^{3}$ & $1.6 \times 10^{3}$ & 830 & $1.4 \times 10^{3}$ & 180 \\
\hline AOA DNA & 330 & $2.2 \times 10^{3}$ & $4.3 \times 10^{3}$ & $2.8 \times 10^{3}$ & 110 & 47 & $1.7 \times 10^{3}$ & 800 & n.d. & \\
\hline AOA cDNA & n.d. & & n.d. & & n.d. & & n.d. & & n.d. & \\
\hline
\end{tabular}

SD, standard deviation; n.d., below detection.

correlated with salinity, temperature, ammonium and nitrate content (based on 999 Monte Carlo permutations, $p=0.001$ ) (Figure 3). The variables in the first and second axes explained 49.6 and $47.2 \%$ of the total variation of $\mathrm{AOB}$ and $\mathrm{AOA}$ composition, respectively.

Environmental variables influenced also the abundance of ammonia oxidizers. Across all samples, both $\beta$-AOB (Spearman, $r=0.59, p<0.01, n=15$ ) and AOA (Spearman, $r=0.73$, $p<0.01, n=15)$ amoA abundance were positively correlated with salinity and organic matter (AOB: Spearman, $r=0.87$, $p<0.01, n=15$; AOA: Spearman, $r=0.60, p<0.05$, $n=15)$. Abundance of $\beta$-AOB amoA gene also correlated with ammonium content (Spearman, $r=0.78, p<0.05, n=$ 15). No significant correlation was found between abundance of ammonia oxidizers and other environmental variables (measured in this study).

\section{Potential Nitrification Rate (PNR)}

The potential nitrification rate was measured using the isotope $\left({ }^{15} \mathrm{~N}\right.$ nitrate) dilution method (Kirkham and Bartholomew, 1954) and the measurements covered the four seasons during 2010 and 2011. The potential rate of nitrification varied between stations as well as between seasons and ranged from 34 to $537 \mu \mathrm{mol}$ $\mathrm{N} \mathrm{m}^{-2} \mathrm{~d}^{-1}$ (Table 6). At all three stations the potential rate of nitrification showed a similar seasonal pattern with higher rates occurring in November and January and lowest rates occurring in July and September (Figure 4). The highest rate was measured at Station $3\left(537 \mu \mathrm{mol} \mathrm{N} \mathrm{m}{ }^{-2} \mathrm{~d}^{-1}\right)$ while the lowest was detected at Station 2. The potential rate of nitrification was always lowest at Station 2, irrespective of the season.

\section{DISCUSSION}

The GeoChip analyses revealed that ammonia-oxidizing bacteria and archaea are common in the microbial mats of the North Sea barrier island Schiermonnikoog. AOB and AOA amoA genes that were detected by GeoChip were distributed throughout the phylogenetic trees of $\mathrm{AOB}$ and $\mathrm{AOA}$ amoA. The $\mathrm{AOB}$ amoA sequences in the microbial mat were dominated by clusters $B$ and C, which both relate to Nitrosospira cluster 3, first described by Purkhold et al. (2003). This is consistent with what other studies reported. Nitrosospira cluster 3 is found predominantly in brackish and marine environments (Francis et al., 2003; Bernhard et al., 2005; Freitag et al., 2006; Wankel et al., 2011). A considerable number of sequences was found that belong to Nitrosomonas. The AOB in Nitrosomonas spanned a wide range of physiological types and inhabit oligohaline to polyhaline environments (Koops and Pommerening-Roser, 2001; Francis et al., 2003). The AOA amoA sequences detected in the microbial mats investigated in this study have been found in a variety of other habitats, such as corals (Brochier-Armanet et al., 2008), hot springs (Zhang et al., 2008), estuaries (Santoro et al., 2008), marine sediments (Francis et al., 2005), and soil (Onodera et al., 2010). In a previous $16 \mathrm{~S}$ rRNA gene based amplicon sequencing study of the same microbial mats (Bolhuis and Stal, 2011) a small number of $\mathrm{AOB}$ sequences (less than $0.01 \%$ of the total community) related to the Nitrosomonadales was found. In two metagenomic datasets of these microbial mats the AOB genus Nitrosococcus and Nitrosomonas were found at $\sim 0.5$ and $0.2 \%$ of the total identified genus, respectively (unpublished). In none of these studies AOA sequences were found. However, due to the 

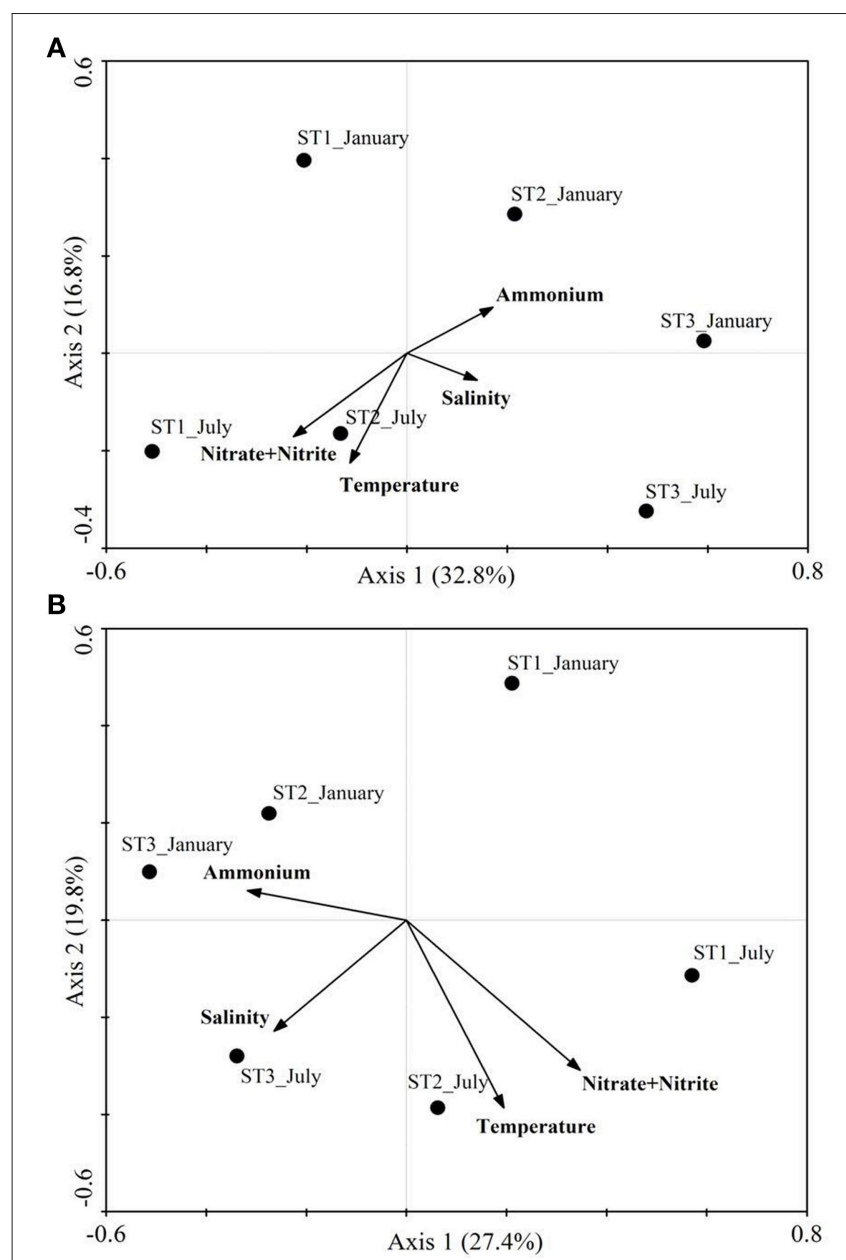

FIGURE 3 | Canonical correspondence analysis of amoA community composition of mat samples. (A) $\beta-A O B$ amoA gene, (B) $A O A$ amoA gene. Points represent the amoA gene community from seasonal samples at the indicated station. Arrows represent the relationship between environmental parameters with the amoA communities.

different nature of the experiments in the studies cited above and in the present study (DNA hybridization vs. PCR bases gene amplification vs. whole genome sequencing) a comparison between these studies is difficult. The high diversity of ammonia oxidizers that we observed can be explained by the large variety of potential microhabitats in the microbial mats that are generated by the daily fluctuations of geochemical parameters and by the activity of the mat microbes.

The richness and diversity estimators (Shannon-Weaver) indicated that Station 1 harbored a more diverse ammoniaoxidizing community than the other two stations. Cluster analysis showed that the bacterial and archaeal amoA composition both grouped Station 2 and Station 3 apart from Station 1 (Figure 2). MRPP analysis of the ammonia oxidizer community ( $\mathrm{AOB}$ and $\mathrm{AOA}$ ) confirmed that Station 2 was more similar to Station 3 than either of these stations to Station 1 . This agrees with what was found for the community of denitrifiers (nirS and nirK) in these mats (Fan et al., 2015) and

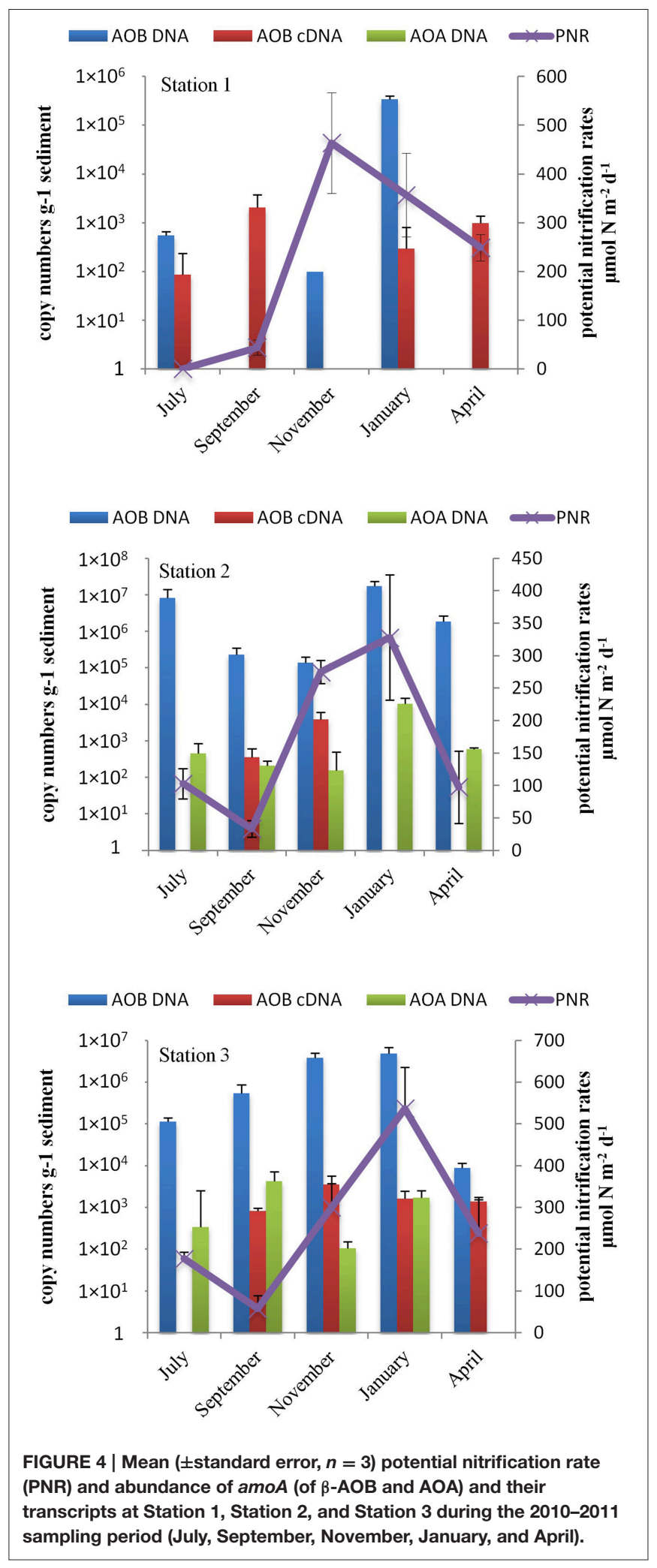

for the community of nitrogen fixers (nifH) (Severin et al., 2012). This suggests that the community composition of the different functional groups of microorganisms involved in the nitrogen 
cycle is determined by the same physical and geochemical factors that prevail in the three types of microbial mats. Previous studies of the eukaryal, bacterial and archaeal diversity (based on ribosomal RNA genes) of these mats revealed that community composition and microbial diversity were intrinsic of the mat type (Bolhuis and Stal, 2011; Bolhuis et al., 2013). Here we show that this also applies for a functional gene for ammonia oxidation.

The richness and diversity of bacterial amoA showed more seasonal changes than those of the archaeal amoA, with the exception of Station 2. The fluctuation of richness and diversity for archaeal $a m o A$ at Station 2 may be due to the tidal inundation by seawater. We expected that the richness and diversity might be higher in winter because other studies showed that AOA were more abundant in winter in the North Sea (Wuchter et al., 2006). However, our results showed that this scenario did not occur in the coastal microbial mats. Cluster analysis showed that the AOB composition at Station 2 was more affected by seasonal changes. The possible explanation is that the mat is disappearing at Station 2 during the year, while the other mats are perennial.

AOB amoA copy numbers were similar to those reported from estuaries (Caffrey et al., 2007; Santoro et al., 2008), salt marshes (Dollhopf et al., 2005) and coastal aquifer sediments (Mosier and Francis, 2008), whereas AOA amoA copy numbers in our study were comparable with those in the cold seep surface sediment $\left(10^{2}-10^{4}\right.$ copies $\mathrm{g}^{-1}$ sediment) (Dang et al., 2010) but were two to three orders of magnitude lower than reported for other estuarine and coastal sediments $\left(10^{4}-10^{7}\right.$ copies $\mathrm{g}^{-1}$ sediment) (Mosier and Francis, 2008; Santoro et al., 2008). The amoA copy number of neither AOB nor AOA correlated with the potential rate of nitrification. This has also been found in other studies (Caffrey et al., 2007; Santoro et al., 2010; Wankel et al., 2011). For instance, Caffrey et al. (2007) did not find a correlation between the number of AOA in the sediment and the potential nitrification rate at four out of six sites in an estuary. Likewise, Santoro et al. (2010) did not find a correlation of either $\mathrm{AOB}$ or $\mathrm{AOA} a m o A$ abundance with nitrification rate in the central California Current. The lack of a correlation may have various reasons. Firstly, it is possible that different types of ammonia-oxidizers have different potential rates of ammonia oxidation per cell (Santoro et al., 2010). It is not precisely known whether certain phylotypes, defined by their 16S rRNA gene sequence, share the same physiological characteristics (Prosser and Nicol, 2012). Secondly, it is possible that only part of the nitrifying populations was active and responsible for the nitrification in microbial mats. The lack of positive correlation between $\mathrm{AOB}$ amoA gene abundance and its transcripts in this study supports the explanation that only part of the nitrifying community was active. Moreover, there is evidence that $\mathrm{AOB}$ and $\mathrm{AOA}$ are capable of mixotrophic (Qin et al., 2014) or heterotrophic growth (Jia and Conrad, 2009), thus the presence of $\mathrm{AOB}$ or $\mathrm{AOA}$ does not necessary mean that they oxidize ammonia. In addition, the function of archaeal ammonia monooxygenase is not clear (Prosser and Nicol, 2012). Therefore, $\mathrm{AOB}$ or AOA abundance and diversity should not be considered as a proxy for nitrification. Ammonia oxidizers that belong to the Gammaproteobacteria might also contribute to nitrification (Lam et al., 2007). However, the GeoChip showed a negligible signal for nitrifiers of the Gammaproteobacteria when compared to $\beta$-AOB and $\mathrm{AOA}$. Therefore, it was concluded that it is unlikely that Gammaproteobacteria play a role of importance in ammonia oxidation in the studied microbial mats.

Some studies reported that AOA are more abundant than AOB in marine (Mincer et al., 2007) and terrestrial ecosystems (Leininger et al., 2006; Shen et al., 2008). Meanwhile, mounting evidence from various estuarine and coastal studies suggested that in certain regions $\mathrm{AOB}$ amoA gene abundance is higher than that of AOA amoA (Caffrey et al., 2007; Mosier and Francis, 2008; Santoro et al., 2008; Wankel et al., 2011). We show that in coastal microbial mats AOB were two to four orders of magnitude more abundant than AOA. On the one hand, AOA amoA was not expressed at detectable levels in the microbial mats despite the high diversity of the gene. On the other hand, the AOB $a m o A$ transcripts positively correlated with potential nitrification rates (Pearson, $r=0.638, p<0.05, n=13$ ). Moreover, multiple stepwise linear regressions showed that $\beta$-AOB amo $A$ transcription was the only valid predictor (out of the variables measured in this study) of the rate of potential nitrification $\left(r^{2}=\right.$ 0.516, $p<0.05$; $r$ for the whole model). AOB amoA transcripts variation explained $51 \%$ of the rate of potential nitrification. This evidence suggests that $\mathrm{AOB}$ are predominantly responsible for nitrification in the microbial mats investigated in this study.

A study on the archaeal diversity in the same mats as in this study revealed that sequence reads assigned to Thaumarchaeota were present in low numbers, hence, confirmed the low abundance of this group in the mats (Bolhuis and Stal, 2011). There are several explanations for the minor importance of AOA in nitrification in the mat. Firstly, salinity appears to play a role in the relative distribution of $\mathrm{AOA}$ and $\beta$-AOB. Mosier and Francis (2008) found that in coastal aquifer sediments with high salinity $(22-31 \mathrm{psu})$ and low $(2-15 \mu \mathrm{M})$ ammonia concentration $\mathrm{AOB}$ were more abundant than AOA but that at low salinity (0.2-9 psu) the latter prevailed. A similar study across a groundwater seawater beach interface also revealed that AOB amoA abundance exceeded AOA amoA abundance with proximity to the ocean and higher salinity (Santoro et al., 2008). The salinities of the microbial mats in this study were generally polyhaline. Secondly, the pore water of the mat contains relatively high ammonium concentrations. The majority of AOA found in this study belonged to Nitrosopumilus. This lineage is represented by Nitrosopumilus maritimus, which appears to be adapted to growth at low ammonia concentrations (MartensHabbena et al., 2009). This may also be the case for AOA in our mats, although some Nitrososphaera strains tolerate higher ammonium concentrations (Verhamme et al., 2011). It is possible that AOA are not obligate ammonia-oxidizers and this would explain the positive correlation between abundance of AOA amoA gene and organic matter (Mußmann et al., 2011). Alves et al. (2013) showed that AOA belonging to Nitrososphaera are functional heterogeneous and that some would not exclusively grow at the expense of ammonia oxidation.

Constrained correspondence analysis showed that the community composition of both AOA and AOB was influenced by the same factors: salinity, temperature and DIN. The lower 
salinity at Station 1 may explain the high diversity and distinct ammonia oxidizer community compared to the other two stations. Bernhard et al. (2010) observed that the loss of diversity of ammonia-oxidizing bacteria correlated with increasing salinity in the Plum Island Sound estuary. Salinity influenced not only the composition of the ammonia-oxidizing community but also the abundance of ammonia oxidizers. In this study, AOA and $\beta$-AOB $a m o A$ abundance were both significantly and positively correlated with salinity. The literature does not reveal consistent conclusions with respect to the effect of salinity on ammonium oxidizers. In San Francisco Bay, AOA amo $A$ abundance was negatively correlated with salinity and $\beta$-AOB amo $A$ abundance was positively correlated with salinity (Mosier and Francis, 2008). However, Caffrey et al. (2007) reported that AOA amoA abundance was positively correlated with salinity, while no correlation was observed between $\mathrm{AOB}$ amoA abundance and salinity. These discrepancies indicate that the factors that control the ammonia oxidizer community and amoA abundance are complex and not well understood. Salinity alone does certainly not explain the observations sufficiently.

Ammonium concentration is a crucial factor that may determine the community composition of ammonia oxidizers because they differ largely in affinity and tolerance toward ammonia (Prosser and Nicol, 2012). For instance, ammonium concentration influenced $\mathrm{AOB}$ community composition and AOB abundance more than in the case of AOA. Particularly, the relative contribution of Nitrosospira cluster B [is related to Nitrosospira cluster 3 as described by Purkhold et al. (2003)] is positively correlated with ammonium concentration (Pearson, $r=0.95, p=0.01, n=5)$. This is in line with the observation that Nitrosospira cluster 3 responded best to high ammonia concentration (Verhamme et al., 2011). The two dimensions of CCA explained only part of the total variance of the ammonia oxidizer community. This implied that other factors must be involved. Many physical and geochemical factors have been proposed including oxygen availability, sulfide concentration (Joye and Hollibaugh, 1995), light (Horrigan and Springer, 1990), and trace metal availability (Mosier and Francis, 2008). All those factors are important in microbial mats but were not taken into account in this study.

The seasonal patterns of potential nitrification observed in the three stations were similar. The low potential nitrification rates in July may be due to competition for ammonium between ammonia oxidizers and cyanobacteria that use it as nitrogen source (in Station 2 also diatoms may compete for the ammonia).
Cyanobacteria are the main structural component of these coastal microbial mats. The microbial mat reaches maturity in summer and becomes less productive and the standing stock biomass decreases afterwards (Stal et al., 1985). Nitrification is an aerobic process and therefore in summer can only happen in the light when the cyanobacteria evolve oxygen as the result of photosynthesis. However, the cyanobacteria then also fix $\mathrm{CO}_{2}$ and assimilate ammonium for growth (Stal, 2003). Hence, the competition pressure in summer may lead to the lower potential nitrification rate compared to other seasons, when the mats are less active and presumably do not become anaerobic. Also in the coastal Arctic Ocean potential nitrification rates were higher in winter than in summer (Christman et al., 2011). These authors hypothesized that the lack of competition for ammonium with phytoplankton and other microorganisms would stimulate nitrification in winter. Also in line with this was the conclusion of Risgaard-Petersen et al. (2004) that benthic algae are superior to $\mathrm{AOB}$ when it comes to competition for ammonium. The seasonal pattern of potential nitrification rates may also be attributed to the dynamics of the community composition of ammonia oxidizers. CCA indicated a seasonal trend for both bacterial and archaeal ammonia oxidizers that correlated particularly to the concentrations of ammonium and nitrate/nitrite. We observed signal intensity shifts in the GeoChip for different types of bacterial ammonia oxidizers between July and January. Because different ammonia oxidizers will have different physiological characteristics, the shift in the community composition may eventually result in the seasonality of nitrification.

\section{AUTHOR CONTRIBUTIONS}

HF designed and carried out the experiments, interpreted the data and wrote the manuscript. HB designed the experiments, interpreted the data and wrote the manuscript. LS designed the project, supervised the experiments, wrote the manuscript.

\section{ACKNOWLEDGMENTS}

This work was financially supported by Dutch Organization for Scientific Research, Earth and Life Science (NWO-ALW) grant 839.08.332. We thank Veronique Confurius and Dr. Juliette Ly for their help with the fieldwork. The authors are indebted to Dr. Jizhong (Joe) Zhou and his team at the University of Oklahoma for hosting HF to carry out the GeoChip analyses.

\section{REFERENCES}

Alves, R. J. E., Wanek, W., Zappe, A., Richter, A., Svenning, M. M., Schleper, C., et al. (2013). Nitrification rates in Arctic soils are associated with functionally distinct populations of ammonia-oxidizing archaea. ISME J. 7, 1620-1631. doi: 10.1038/ismej.2013.35

Bernhard, A. E., Donn, T., Giblin, A. E., and Stahl, D. A. (2005). Loss of diversity of ammonia-oxidizing bacteria correlates with increasing salinity in an estuary system. Environ. Microbiol. 7, 1289-1297. doi: 10.1111/j.14622920.2005.00808.x

Bernhard, A. E., Landry, Z. C., Blevins, A., de la Torre, J. R., Giblin, A. E., and Stahl, D. A. (2010). Abundance of ammonia-oxidizing Archaea and Bacteria along an estuarine salinity gradient in relation to potential nitrification rates. Appl. Environ. Microbiol. 76, 1285-1289. doi: 10.1128/AEM.02018-09

Bolhuis, H., Fillinger, L., and Stal, L. J. (2013). Coastal microbial mat diversity along a natural salinity gradient. PLoS ONE 8:e63166. doi: 10.1371/journal.pone.0063166

Bolhuis, H., and Stal, L. J. (2011). Analysis of bacterial and archaeal diversity in coastal microbial mats using massive parallel 16S rRNA gene tag sequencing. ISME J. 5, 1701-1712. doi: 10.1038/ismej.2011.52 
Brochier-Armanet, C., Boussau, B., Gribaldo, S., and Forterre, P. (2008). Mesophilic Crenarchaeota: proposal for a third archaeal phylum, the Thaumarchaeota. Nat. Rev. Microbiol. 6, 245-252. doi: 10.1038/nrmicro1852

Caffrey, J. M., Bano, N., Kalanetra, K., and Hollibaugh, J. T. (2007). Ammonia oxidation and ammonia-oxidizing bacteria and archaea from estuaries with differing histories of hypoxia. ISME J. 1, 660-662. doi: 10.1038/ismej. 2007.79

Christman, G. D., Cottrell, M. T., Popp, B. N., Gier, E., and Kirchman, D. L. (2011). Abundance, diversity, and activity of ammonia-oxidizing prokaryotes in the coastal arctic ocean in summer and winter. Appl. Environ. Microbiol. 77, 2026-2034. doi: 10.1128/AEM.01907-10

Dang, H., Luan, X.-W., Chen, R., Zhang, X., Guo, L., and Klotz, M. G. (2010). Diversity, abundance and distribution of amoA-encoding archaea in deep-sea methane seep sediments of the Okhotsk Sea. FEMS Microbiol. Ecol. 72, 370-385. doi: 10.1111/j.1574-6941.2010.00870.x

Davidson, E. A., and Seitzinger, S. (2006). The enigma of progress in denitrification research. Ecol. Appl. 16, 2057-2063. doi: 10.1890/10510761(2006)016[2057:TEOPID]2.0.CO;2

Dollhopf, S. L., Hyun, J. H., Smith, A. C., Adams, H. J., O’Brien, S., and Kostka, J. E. (2005). Quantification of ammonia-oxidizing bacteria and factors controlling nitrification in salt marsh sediments. Appl. Environ. Microbiol. 71, 240-246. doi: 10.1128/AEM.71.1.240-246.2005

Fan, H., Bolhuis, H., and Stal, L. J. (2015). Denitrification and the denitrifier community in a coastal microbial mat. FEMS Microbiol. Ecol. 91: fiu033. doi: 10.1093/femsec/fiu033

Francis, C. A., O’Mullan, G. D., and Ward, B. B. (2003). Diversity of ammonia monooxygenase $(a m o A)$ genes across environmental gradients in Chesapeake Bay sediments. Geobiolgy 1, 129-140. doi: 10.1046/j.1472-4669.2003. 00010.x

Francis, C. A., Roberts, K. J., Beman, J. M., Santoro, A. E., and Oakley, B. B. (2005). Ubiquity and diversity of ammonia-oxidizing archaea in water columns and sediments of the ocean. Proc. Natl. Acad. Sci. U.S.A. 102, 14683-14688. doi: 10.1073/pnas.0506625102

Freitag, T. E., Chang, L., and Prosser, J. I. (2006). Changes in the community structure and activity of betaproteobacterial ammonia-oxidizing sediment bacteria along a freshwater-marine gradient. Environ. Microbiol. 8, 684-696. doi: 10.1111/j.1462-2920.2005.00947.x

Gribsholt, B., Boschker, H. T. S., Struyf, E., Andersson, M., Tramper, A., De Brabandere, L., et al. (2005). Nitrogen processing in a tidal freshwater marsh: a whole-ecosystem N-15 labeling study. Limnol. Oceanogr. 50, 1945-1959. doi: 10.4319/lo.2005.50.6.1945

Herbert, R. A. (1999). Nitrogen cycling in coastal marine ecosystems. FEMS Microbiol. Rev. 23, 563-590. doi: 10.1111/j.1574-6976.1999.tb00414.x

Horrigan, S. G., and Springer, A. L. (1990). Oceanic and estuarine ammonium oxidation - effects of light. Limnol. Oceanogr. 35, 479-482. doi: 10.4319/lo.1990.35.2.0479

Jetten, M. S. M., Strous, M., van de Pas-Schoonen, K. T., Schalk, J., van Dongen, U. G. J. M., van de Graaf, A. A., et al. (1998). The anaerobic oxidation of ammonium. FEMS Microbiol. Rev. 22, 421-437. doi: 10.1111/j.15746976.1998.tb00379.x

Jia, Z., and Conrad, R. (2009). Bacteria rather than Archaea dominate microbial ammonia oxidation in an agricultural soil. Environ. Microbiol. 11, 1658-1671. doi: 10.1111/j.1462-2920.2009.01891.x

Joye, S. B., and Hollibaugh, J. T. (1995). Influence of sulfide inhibition of nitrification on nitrogen regeneration in sediments. Science 270, 623-625. doi: 10.1126 /science.270.5236.623

Kirkham, D., and Bartholomew, W. V. (1954). Equations for following nutrient transformations in soil, utilizing tracer data. Soil Sci. Soc. Am. J. 18, 33-34. doi: 10.2136/sssaj1954.03615995001800010009x

Könneke, M., Bernhard, A. E., de la Torre, J. R., Walker, C. B., Waterbury, J. B., and Stahl, D. A. (2005). Isolation of an autotrophic ammonia-oxidizing marine archaeon. Nature 437, 543-546. doi: 10.1038/nature03911

Koops, H. P., and Pommerening-Roser, A. (2001). Distribution and ecophysiology of the nitrifying bacteria emphasizing cultured species. FEMS Microbiol. Ecol. 37, 1-9. doi: 10.1111/j.1574-6941.2001.tb00847.x

Kowalchuk, G. A., and Stephen, J. R. (2001). Ammonia-oxidizing bacteria: a model for molecular microbial ecology. Annu. Rev. Microbiol. 55, 485-529. doi: 10.1146/annurev.micro.55.1.485
Lam, P., Jensen, M. M., Lavik, G., McGinnis, D. F., Müller, B., Schubert, C. J., et al. (2007). Linking crenarchaeal and bacterial nitrification to anammox in the Black Sea. Proc. Natl. Acad. Sci. U.S.A. 104, 7104-7109. doi: 10.1073/pnas.0611081104

Leininger, S., Urich, T., Schloter, M., Schwark, L., Qi, J., Nicol, G. W., et al. (2006). Archaea predominate among ammonia-oxidizing prokaryotes in soils. Nature 442, 806-809. doi: 10.1038/nature04983

Liang, Y., He, Z., Wu, L., Deng, Y., Li, G., and Zhou, J. (2010). Development of a common oligonucleotide reference standard for microarray data normalization and comparison across different microbial communities. Appl. Environ. Microbiol. 76, 1088-1094. doi: 10.1128/AEM.02749-09

Martens-Habbena, W., Berube, P. M., Urakawa, H., de la Torre, J. R., and Stahl, D. A. (2009). Ammonia oxidation kinetics determine niche separation of nitrifying Archaea and Bacteria. Nature 461, 976-981. doi: 10.1038/nature08465

McCune, B., Grace, J. B., and Urban, D. L. (2002). Analysis of Ecological Communities, Vol. 28. Gleneden Beach, OR: MjM Software Design.

Mincer, T. J., Church, M. J., Taylor, L. T., Preston, C., Karl, D. M., and DeLong, E. F. (2007). Quantitative distribution of presumptive archaeal and bacterial nitrifiers in Monterey Bay and the North Pacific Subtropical Gyre. Environ. Microbiol. 9, 1162-1175. doi: 10.1111/j.1462-2920.2007.01239.x

Mosier, A. C., and Francis, C. A. (2008). Relative abundance and diversity of ammonia-oxidizing archaea and bacteria in the San Francisco Bay estuary. Environ. Microbiol. 10, 3002-3016. doi: 10.1111/j.1462-2920.2008.01764.x

Mußmann, M., Brito, I., Pitcher, A., Sinninghe Damsté, J. S., Hatzenpichler, R., Richter, A., et al. (2011). Thaumarchaeotes abundant in refinery nitrifying sludges express amoA but are not obligate autotrophic ammonia oxidizers. Proc. Natl. Acad. Sci. U.S.A. 108, 16771-16776. doi: 10.1073/pnas.1106427108

Norton, J. M., and Stark, J. M. (2011). Regulation and measurement of nitrification in terrestrial systems. Meth. Enzymol. 486, 343-368. doi: 10.1016/B978-0-12381294-0.00015-8

Oksanen, J. (2011). Multivariate Analysis of Ecological Communities in R: Vegan Tutorial. R package version: 2.0-1. Oulu: University of Oulu.

Onodera, Y., Nakagawa, T., Takahashi, R., and Tokuyama, T. (2010). Seasonal change in vertical distribution of ammonia-oxidizing archaea and bacteria and their nitrification in temperate forest soil. Microbes Environ. 25, 28-35. doi: 10.1264/jsme2.ME09179

Pester, M., Rattei, T., Flechl, S., Gröngröft, A., Richter, A., Overmann, J., et al. (2012). amoA-based consensus phylogeny of ammonia-oxidizing archaea and deep sequencing of amoA genes from soils of four different geographic regions. Environ. Microbiol. 14, 525-539. doi: 10.1111/j.14622920.2011.02666.x

Prosser, J. I., and Nicol, G. W. (2012). Archaeal and bacterial ammonia-oxidisers in soil: the quest for niche specialisation and differentiation. Trends Microbiol. 20, 523-531. doi: 10.1016/j.tim.2012.08.001

Purkhold, U., Wagner, M., Timmermann, G., Pommerening-Röser, A., and Koops, H.-P. (2003). 16S rRNA and amoA-based phylogeny of 12 novel betaproteobacterial ammonia-oxidizing isolates: extension of the dataset and proposal of a new lineage within the nitrosomonads. Int. J. Syst. Evol. Microbiol. 53, 1485-1494. doi: 10.1099/ijs.0.02638-0

Qin, W., Amin, S. A., Martens-Habbena, W., Walker, C. B., Urakawa, H., Devol, A. H., et al. (2014). Marine ammonia-oxidizing archaeal isolates display obligate mixotrophy and wide ecotypic variation. Proc. Natl. Acad. Sci. U.S.A. 111, 12504-12509. doi: 10.1073/pnas.1324115111

Revsbech, N. P., Jørgensen, B. B., Blackburn, T. H., and Cohen, Y. (1983). Microelectrode studies of the photosynthesis and $\mathrm{O}_{2}, \mathrm{H}_{2} \mathrm{~S}$ and $\mathrm{pH}$ profiles of a microbial mat. Limnol. Oceanogr. 28, 1062-1074. doi: 10.4319/lo.1983.28.6.1062

Risgaard-Petersen, N., Nicolaisen, M. H., Revsbech, N. P., and Lomstein, B. A. (2004). Competition between ammonia-oxidizing bacteria and benthic microalgae. Appl. Environ. Microbiol. 70, 5528-5537. doi: 10.1128/AEM.70.9.5528-5537.2004

Rotthauwe, J. H., Witzel, K. P., and Liesack, W. (1997). The ammonia monooxygenase structural gene $a m o A$ as a functional marker: molecular fine-scale analysis of natural ammonia-oxidizing populations. Appl. Environ. Microbiol. 63, 4704-4712.

Santoro, A. E., Casciotti, K. L., and Francis, C. A. (2010). Activity, abundance and diversity of nitrifying archaea and bacteria in the central California Current. Environ. Microbiol. 12, 1989-2006. doi: 10.1111/j.1462-2920.2010.02205.x 
Santoro, A. E., Francis, C. A., de Sieyes, N. R., and Boehm, A. B. (2008). Shifts in the relative abundance of ammonia-oxidizing bacteria and archaea across physicochemical gradients in a subterranean estuary. Environ. Microbiol. 10, 1068-1079. doi: 10.1111/j.1462-2920.2007.01547.x

Severin, I., Confurius-Guns, V., and Stal, L. J. (2012). Effect of salinity on nitrogenase activity and composition of the active diazotrophic community in intertidal microbial mats. Arch. Microbiol. 194, 483-491. doi: 10.1007/s00203011-0787-5

Severin, I., and Stal, L. J. (2010). "Diazotrophic microbial mats," in Microbial Mats. Modern and Ancient Microorganisms in Stratified Systems (Heidelberg; Springer), 321-339.

Shen, J.-P., Zhang, L.-M., Zhu, Y.-G., Zhang, J.-B., and He, J.-Z. (2008). Abundance and composition of ammonia-oxidizing bacteria and ammonia-oxidizing archaea communities of an alkaline sandy loam. Environ. Microbiol. 10, 1601-1611. doi: 10.1111/j.1462-2920.2008.01578.x

Stal, L. J. (2003). "Nitrogen cycling in marine cyanobacterial mats" in Fossil and Recent Biofilms: A Natural History of Life on Earth, eds W. E. Krumbein, D. M. Paterson, and G. A. Zavarzin (Springer. pp. 119-140.

Stal, L. J., van Gemerden, H., and Krumbein, W. E. (1985). Structure and development of a benthic marine microbial mat. FEMS Microbiol. Ecol. 31, 111-125. doi: 10.1111/j.1574-6968.1985.tb01138.x

Tamura, K., Stecher, G., Peterson, D., Filipski, A., and Kumar, S. (2013). MEGA6: molecular evolutionary genetics analysis version 6.0. Mol. Biol. Evol. 30, 2725-2729. doi: 10.1093/molbev/mst197

Team, R. D. C. (2011). R: A Language and Environment for Statistical Computing. Vienna, Austria: R Foundation for Statistical Computing; 2008. Available onlline at: http://www.R-project.org

ter Braak, C. J. (1989). CANOCO-an extension of DECORANA to analyze species-environment relationships. Hydrobiologia 184, 169-170. doi: 10.1007/BF02392953

Tu, Q., Yu, H., He, Z., Deng, Y., Wu, L., Van Nostrand, J. D., et al. (2014). GeoChip 4: a functional gene-array-based high-throughput environmental technology for microbial community analysis. Mol. Ecol. Res. 14, 914-928. doi: 10.1111/1755-0998.12239
Venter, J. C., Remington, K., Heidelberg, J. F., Halpern, A. L., Rusch, D., Eisen, J. A., et al. (2004). Environmental genome shotgun sequencing of the Sargasso Sea. Science 304, 66-74. doi: 10.1126/science. 1093857

Verhamme, D. T., Prosser, J. I., and Nicol, G. W. (2011). Ammonia concentration determines differential growth of ammonia-oxidising archaea and bacteria in soil microcosms. ISME J. 5, 1067-1071. doi: 10.1038/ismej. 2010.191

Wankel, S. D., Mosier, A. C., Hansel, C. M., Paytan, A., and Francis, C. A. (2011). Spatial Variability in Nitrification rates and ammonia-oxidizing microbial communities in the agriculturally impacted Elkhorn Slough estuary, California. Appl. Environ. Microbiol. 77, 269-280. doi: 10.1128/AEM.01 318-10

Wu, L., Liu, X., Schadt, C. W., and Zhou, J. (2006). Microarray-based analysis of subnanogram quantities of microbial community DNAs by using wholecommunity genome amplification. Appl. Environ. Microbiol. 72, 4931-4941. doi: 10.1128/AEM.02738-05

Wuchter, C., Abbas, B., Coolen, M. J., Herfort, L., van Bleijswijk, J., Timmers, P., et al. (2006). Archaeal nitrification in the ocean. Proc. Natl. Acad. Sci. U.S.A. 103, 12317-12322. doi: 10.1073/pnas.0600756103

Zhang, C. L., Ye, Q., Huang, Z., Li, W., Chen, J., Song, Z., et al. (2008). Global occurrence of archaeal $a m o A$ genes in terrestrial hot springs. Appl. Environ. Microbiol. 74, 6417-6426. doi: 10.1128/AEM.00843-08

Conflict of Interest Statement: The authors declare that the research was conducted in the absence of any commercial or financial relationships that could be construed as a potential conflict of interest.

Copyright (C) 2015 Fan, Bolhuis and Stal. This is an open-access article distributed under the terms of the Creative Commons Attribution License (CC BY). The use, distribution or reproduction in other forums is permitted, provided the original author(s) or licensor are credited and that the original publication in this journal is cited, in accordance with accepted academic practice. No use, distribution or reproduction is permitted which does not comply with these terms. 